\title{
SIMETRIS PRESISI: WAJAH ARSITEKTUR KOLONIAL KOTA TAMBANG SAWAHLUNTO
}

\section{SYMMETRICAL PRECISION: THE COLONIAL ARCHITECTURE FACE OF SAWAHLUNTO MINE CITY}

\author{
Asyhadi Mufsi Sadzali \\ Program Studi Arkeologi Fakultas IImu Budaya Universitas Jambi \\ asyhadi mufsi@unja.ac.id
}

Naskah diterima: 27 April 2019; direvisi: 16 Mei 2019; disetujui: 20 Juni 2019

\begin{abstract}
Abstrak
Banyak kota di dunia yang secara massive mengembangkan konsep arsitektur yang dilandasi oleh beragam faktor, semisal konsep arsitketur yang dipengaruhi faktor lingkungan, gaya hidup filosofis religi, aspek simbolis tradisional, juga terkiat fungsi guna lahan semisal pertambangan. Pada landasan faktor terkahir, mamunculkan beberapa contoh kota tambang yang secara konsep oleh para arsiteknya diberi wajah kota yang khas sesuai dengan fungsi lahan 'yakni tambang'. Pada pendalaman kajian arsitektur yang dilakukan, maka dalam hal ini peneliti menguraikan data arkeologi berupa bangunan kolonial dengan menggunakan metode arkeologi, yang selanjutnya secara spesifik terdiri dari tahap pengumpulan data pustaka, pengumpulan data arkeologi, identifikasi data arsitektur, analysis data (morfologi, fungsi bangunan, dan gaya arsitektur), sehingga kemudian dapat ditarik suatu kesimpulan. Hipotesa yang ditemukan bahwa wajah kota tambang kolonial Sawahlunto dihiasi oleh gaya bangunan yang lahir dari adaptasi antara gaya Eropa, dan campuran lokal, namun besar juga dipengauruhi efiseinsi fungsi bangunan. Aspek seni estetis tidak terlalu dimunculkan, sehingga bentuk presisi simetris adalah gaya yang paling menonjol dalam wajah-wajah orang-orang tambang Sawahlunto tempo dulu.
\end{abstract}

Kata Kunci: Arsitektur, Koloial, Tambang, Sawahlunto.

\section{Abstract}

Many cities in the world massively develop architectural concepts based on varieties factor, such as the concept of architecture that is influenced by environmental, philosophical religious lifestyle, traditional symbolic aspects, also the function of land used such as mining. On the last basic of factors, shows several examples of mining cities were presented which conceptually gave a distinctive face of the city in accordance with the function of the land 'namely mine'. In the deepening of architectural studies, Researcher describes archaeological data in the form of colonial buildings that is used archeological methods, which in turn specifically consist of library data collection, archaeological data collection, architectural data identification, data analysis (morphology, building functions, and architectural style), so that the conclusions can be drawn. The hypothesis is the face of the colonial mining of Sawahlunto city was decorated by a building style of adaptation between European styles, and local mixtures, but also the efficiency of the functions of buildings. The aesthetic aspect of the art is not very much raised, so the form of symmetrical precision is the most prominent style in the faces of the people of the Sawahlunto mine in the past.

Keywords: Architecture, Colonial, Mine, Sawahlunto.

PENDAHULUAN

'De Architecture' karya Marcus

Pollio Vitrovius, berpendapat bahwa

arsitektur adalah sebuah kekuatan, keindahan, estetika, dan modifikasi

fungsi alam. Lain dengan Walter

Grophius, arsitektur dimaknai sebagai

suatu ilmu bangunan yang juga 
mencakup masalah-masalah yang berhubungan dengan biologi, sosial, teknik, dan estetika artistik, sehingga arsitektur dapat didefinisikan sebagai: seni ilmu bangunan, termasuk perencanaan, perancangan, konstruksi dan penyelesaian ornament; karakter atau gaya bangunan; proses membangun bangunan; atau kumpulan bangunan-bangunan (Atmadi 1979: 12).

Penelitian terdahulu yang terkait dengan kajian arsitektur, khususnya bangunan tradisional di wilayah Sumatera telah dikaji oleh beberapa peneliti antara lain Sadzali dan Anra (2018) dan Sadzali dan Fitrah (2018) menunjukkan suatu hasil bahwa pada masa sebelum meletusnya revolusi industry di Eropa, kecendrungan patokan konsep arsitektur masih ditekankan terkait makna filosofis dan seni estetis.

Paska revolusi industri meletus di Eropa perkembangan keahlian dibidang teknik dan semakin kompleknya kebutuhan manusia akan ruang habitus atau ruang hunian, turut mendorong semakin berkembangnya ragam bentuk arsitektur yang dikembangkan para arsitek. Kondisi ini ternyata turut mendorong kelahiran kajian arsitketur secara akadmik dan teoritis, yang kemudian oleh para pakar arstitketur memisahkan pengkajian arsitektur kedalam 3 (tiga) aspek yang saling berkaitan namun masih mungkin dapat dibahas secara terpisah, yaitu aspek struktur, aspek makna simbolis, dan aspek fungsi sosial (Sedyawati 1990 : 70). Ditinjau secara penjabaran umumnya dapat dipahami, bahwa aspek struktur merupakan pembahasan yang menitikberatkan pada bentuk struktur suatu bangunan, sedangkan aspek simbolis merupakan suatu kajian terkait simbol-simbol yang melekat pada sebuah bangunan, sedangkan aspek fungsi sosial merupakan suatu kajian terkait fungsi atau kegunaan suatu bangunan.

Sejak meletusnya revolusi industry di Eropa pada abad ke $18 \mathrm{M}$, poin ketiga cukup mendominasi landasan konseptual arsitektur. Banyak kota di dunia, secara massive mengembangkan konsep arsitektur yang dilandasi dengan atas konsentrasi pada fungsi, seperti mislanya konsep arsitketur pabrik yang mengutamakan efisiensi dibandingkan estetis, apalagi soal keharmonisan dengan lingkungan sekitar. Dunia modern lalu menyebutnya sebagai gaya hidup 
masyarakat urban, tanpa cita rasa filosofis religi, aspek simbolis budaya tradisional, dan estteika keagungan seni. Dalam hal ini Sawahlunto masuk dalam daftar panjang arsitketur yang lahir dari semangat revolusi industry Eropa. Disamping Sawahlunto, terdapat beberapa contoh kota tambang lain semisal Lebong di Bengkulu, atau Muntok di Bangka Belitung, yang kemduian secara konseptual oleh para arsitek menciptakan wajah kota sesuai dengan fungsi lahan 'yakni tambang'.

Perlu juga diperhatikan, bahwa lepas dari konsep fungsi guna bangunan, kurun waktu juga menjadi satu patokan dasar yang mempengaruhi suatu bentuk arsitektur. Boleh dkatakan sebagai jiwa zaman atau tren pada masanya. Seingga kemudian muncul sebutan-sebutan periodesasi arstitktur yang diklasifikasikan oleh para peneliti arsitektur semisal; arsitektur klasik, arsitktur neo-gothik, arsitektur masa kesultanan, dan arsitektur masa kolonial Belnda. Adapun arsitektur kolonial adalah sebutan singkat untuk langgam arsitektur yang berkembang selama masa pendudukan Belanda di wilayah Indonesia. Periode ini juga setidaknya dibagi kedalam empat etape; periode pertama Abad 16 s-d 1800 M, periode kedua tahun 1800 s-d 1902 M, periode ketiga tahun 1902 s-d 1920 M, dan periode keempat ahun 1920 s-d 1940 M (Handinoto, 1996: 129-130).

Diantara beberapa kota tambang yang pernah berjaya dimasa kolonial, salah satu yang menarik adalah Kota Tambang Sawahlunto. Kota Sawahlunto merupakan salah satu kota yang lahir dan tumbuh karena adanya pertambangan batubara. Dimana sejak awal kota ini dibangun guna mendukung kegiatan penambangan batubara oleh perusahaan kolonial Belanda. Kota Sawahlunto direncanakan dengan sangat hati-hati dan terpola mengikuti aspirasi pemerintah kolonial saat itu. Pembagian ruang landskap diatur sedemikian rupa, sehingga ada pembagian zonasi; semisal perumahan pegawai tinggi pertambangan ditempatkan dalam satu zona terdekat dengan fasilitas perdagangan serta kantor admisntarsi tambang, sementara permukiman buruh tambang ditempatkan jauh di pinggiran kota. Kamp orang tahanan diposisikan dekat dengan lubang tambang dan penjara, sedangkan zona jasa dan komersial ditempatkan di pusat kota (Suprayoga, 2008: 1) 
Sudut pandang 'sang arsitek' yang berkebangsaan Belanda dalam membagi uang dan membentuk wajah atau fasat bangunan tidak sepenuhnya bergaya Eropa sentris, atau pengaruh occidental (barat), namun tidak sedikit 'sang arsiek' menerapkan konsep lokal atau tradisional dalam merencana dan mengembangkan kota, permukiman dan bangunan-bangunan.

(Sumalyo, 1993:3). Hanya saja, tingkat dominan gaya Eropa dan gaya Lokal, terkadang simbang, dan terkadang berat sebelah, lebih condong gaya Eropa.

Berdasarkan data dari BPCB Sumatera Barat, setidaknya terdapat 74 bangunan, namun dalam tulisan ini hanya akan membahas 13 bangunan; Rumah Dinas Kesehatan, Museum Gudang Ransum, Gedung Pusat UPO, Masjid Nurul Huda, Stasiun Silungkang, Rumah Dansek, Rumah Dinas Wakil Wali Kota Sawahlunto, Sekolah Santa Lucia, Stasiun Muara Kalaban, Pasar Durian, Gereja Khatolik, Koperasi PT TBO, Perpustakaan Adinegoro, Menara PLTU Masjid Agung Nurul Islam. Berdasarkan fenomena dan data arsitektur yang masih dapat kita jumpai di Kota Tambang Sawahlunto, memunculkan bbeerapa pertanyaan mendasar yang sangat menarik dan penting untuk diuraikan dalam suatu penelitian arkeologi, terkhusus arkeologi arsitektur. Pertanyaan penelitian tersebut yakni; 1) Bangunan kolonial apa saja yang terdapat di Kota Tambang Sawahlunto, 2) Bagaimana bentuk arsitektur bangunan kolonial di Kota Sawahlunto, 3) Bagaimana gaya arsitketur yang berkembang di Kota Tambang Sawahlunto? Ketiga pertanyaan peneltian ini selanjutnya akan diuraikan dengan menggunakan landasan teori yang relevan dengan teori arkeologi arsitektur dan dibedah dengan menggunakan pendekatan metode arkeologi, yang secara treprinci akan dijabarkan dalam sub-bab selanjutnya.

\section{LANDASAN TEORI}

Menurut Handinoto arsitektur modern kolonial adalah hasil dari protes tentang gaya Empire Style yang mengutamakan kemegahan dalam seni arsitektur. Arsitektur modern memiliki cirri-ciri denah lebih bervariasi, sesuai dengan anjuran kratifitas dalam arsitektur modern. Bentuk simetri banyak di hindari, pemakaian teras keliling bangunan sudah tidak di pakai lagi, sebagai gantinya sering di pakai elemen penahan sinar. Berusaha untuk 
menghilangkan kesan tampak arsitektur gaya indische enpire (tampak tidak simetri lagi), tampak bangunan lebih mencerminkan form follow function atau clean design. bentuk atap masih didominasi oleh atap pelana atau perisai, dengan bahan penutup genting atau sirap. Sebagian bangunan dengan kontruksi beton, memakai atap datar dari bahan beton yang belum pernah ada zaman sebelumnya.

\section{METODOLOGI}

Penelitian ini menggunakan metode arkeologi yang bersifat sistematis untuk mencapai tujuan yang diharapakan, data utama yang diperlukan berupa arsitektur bangunan kolonial Belanda yang berada di Kota Lama Tambang Batubara Sawahlunto dan tata letak. Adapun langkah-langkah dalam penelitian ini, adalah: pengumpulan data yang terdiri dari data pustaka dan data arkelogi yang dalam kajian ini berupa data arsitektur bangunan kolonial di kota Sawahlunto. Tahapan kledua yakni analaisis data yang terdiri dari analisis bentuk dan gaya bangunan, selanjutnya adalah tahapan pengolahan data gambar bangunan dengan Photoshop dan Autocad kedalam bentuk digital. Tahapan terahir yakni interpretasi data, dimana berdasarkan analisis morfologi dan gaya, maka ditarik suatu hipotesi terkait gaya arsitiktur dan faktor yang mempengaruhinya (Sukendar, 1999).

\section{HASIL DAN PEMBAHASAN Identifikasi Bangunan Kolonial Kota Tambang Sawahlunto.}

Secara astronomis kota Sawahlunto berada pada $0^{0} .34^{\prime}-0^{0} .46$ Lintang Selatan dan $100^{\circ} .41^{\prime}-100^{\circ} .49^{\prime}$ Bujur Timur. Terletak pada ketinggian antara 250-650 meter di atas permukaan laut.Sawahlunto berada di daerah tropis dengan suhu minimum $22,5^{\circ} \mathrm{C}$ dengan curah hujan rata-rata pertahun 1.072 mm.Kota sawahlunto terletak di daerah dataran tinggi pada tengah bukit barisan. Bukit barisan adalah pegunungan yang membujur sepanjang pulau sumatera dan berjarak sekitar 95 $\mathrm{km}$ dari padang, ibukota provinsi Sumatera Barat. (Asoka,2017;1) 


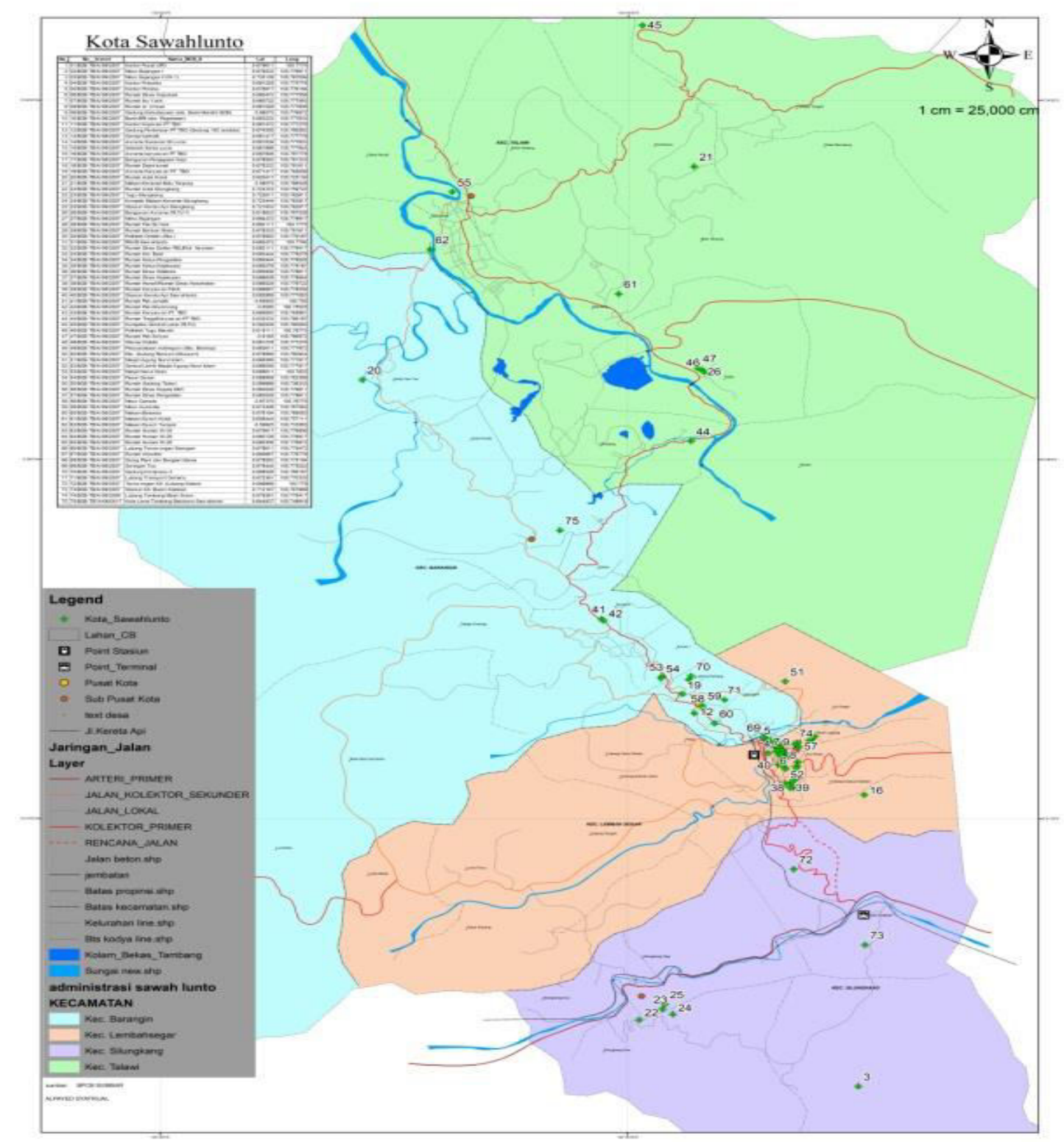

Petal: Kota Sawahlunto

(Sumber: Alpayed, 2018)

Secara

administratif

pemerintahan Kota Lama Sawahlunto dengan batas: Sebelah utara berbatas dengan Nagari Kolok dan Sijantang (Kecamatan Talawi). Sebelah Selatan berbatas dengan Nagari Kubang dan Nagari Silungkang (Kecamatan Sawahlunto).Sebelah Timur dan Barat berbatas dengan Nagari Kubang (Kecamatan Sawahlunto).Sementara itu, "Kota Baru" merupakan "kota lama" yang dimekarkan pada tahun 1990 dengan luas mencapai 27.347,7 Ha. Pemekaran ini dilakukan dengan merangkul nagari-nagari yang berada disekitarnya. Sekarang Kota 
Sawahlunto memiliki batas: Sebelah Utara dengan Kabupaten Tanah Datar. Sebelah Selatan dan Barat dengan Kabupaten Solok. Sebelah Timur dengan Kabupaten Sijunjung. (Asoka, 2017:7)

Pada cakupan kawasan dan bentang alam kota tambang batubara Sawahlunto, setidkanya terdapat empat katogeri bangunan ssuai dengan bentuk, dan fungsinya yakni; bangunan perkntoran, bangunan hunian atau tempat tinggal, bangunan produksi tambang atau pabrik pengolahan batubara, tempat peribadatan dan bangunan pertokoan. Secara lebih terperinci, ragam bangunan tersebut dipaparkan dalam tabel 1 berikut:

Tabel 1.

Identifikasi Bangunan Kolonial Di Kota Sawahlunto

\begin{tabular}{|c|c|c|c|c|}
\hline No & $\begin{array}{c}\text { Bangunan } \\
\text { Kolonial }\end{array}$ & Lokasi & Dekskripsi Bentuk & Fungsi \\
\hline 1 & $\begin{array}{l}\text { Stasiun } \\
\text { Silungkang }\end{array}$ & $\begin{array}{l}\text { Desa Silungkang } \\
\text { III Kecamatan } \\
\text { Silungkang Kota } \\
\text { Sawahlunto } \\
\text { Provinsi Sumatera } \\
\text { Barat. Stasiun ini } \\
\text { terletak di dataran } \\
\text { daerah pegunungan } \\
\text { yang memiliki } \\
\text { letak astronomis } 0^{\circ} \\
43^{\prime} 18,6^{\prime} \text { LS dan } \\
100^{\circ} 45^{\prime} 46,5^{\prime} \text { BT }\end{array}$ & 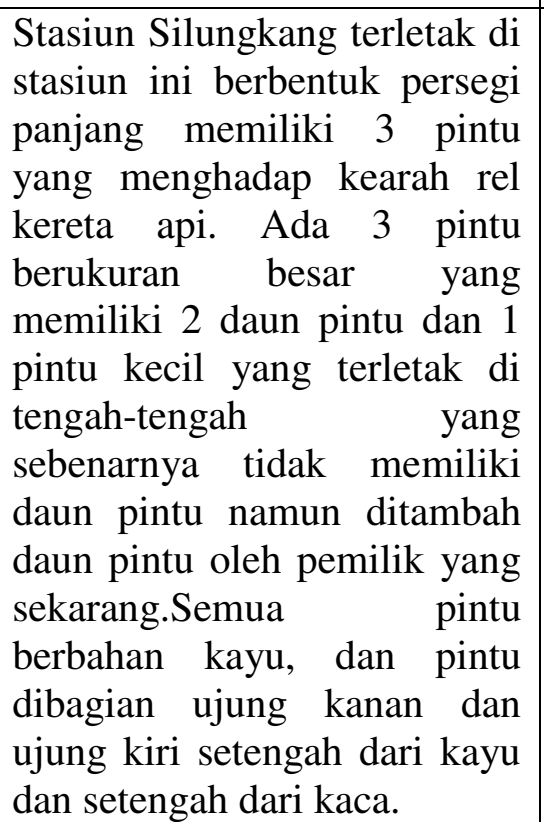 & $\begin{array}{l}\text { Sebagai } \\
\text { stasiun } \\
\text { kereta } \\
\text { pengangkut } \\
\text { batubara dari } \\
\text { Sawahlunto } \\
\text { menuju } \\
\text { Teluk Bayur. }\end{array}$ \\
\hline 2 & $\begin{array}{l}\text { Stasiun } \\
\text { Muara } \\
\text { Kalaban }\end{array}$ & $\begin{array}{l}\text { Desa Muara } \\
\text { Kalaban } \\
\text { Kecamatan } \\
\text { Silungkang Kota } \\
\text { Sawahlunto } \\
\text { Provinsi Sumatera } \\
\text { Barat dengan titik } \\
\text { koordinat } \\
0^{\circ} 42^{\prime} 43,8^{\prime \prime} \text { LS dan } \\
100^{\circ} 47^{\prime} 16,4^{\prime \prime B T}\end{array}$ & $\begin{array}{l}\text { Memiliki } 1 \text { halaman , } 3 \\
\text { pembagian ruangan, ruangan } \\
1 \text { dipakai untuk para pegawai } \\
\text { stasiun. Ruangan ke } 2 \text { dipakai } \\
\text { untuk ruang mesin kereta api, } \\
\text { ruangan } 3 \text { dipakai untuk para } \\
\text { penumpang yang menunggu } \\
\text { dan tempat pembelian karcis } \\
\text { dinding stasiun polos. ukuran } \\
\text { rata-rata pintu tnggi } 190 \mathrm{~cm}, \\
\text { lebar } 80 \mathrm{~cm} \text {, jendela stasiun }\end{array}$ & $\begin{array}{l}\text { Sebagai } \\
\text { stasiun } \\
\text { kereta } \\
\text { pengangkut } \\
\text { batubara dari } \\
\text { Sawahlunto } \\
\text { menuju } \\
\text { Teluk Bayur. }\end{array}$ \\
\hline
\end{tabular}




\begin{tabular}{|c|c|c|c|c|}
\hline & & & $\begin{array}{l}\text { ini berjumlah } 3 \text { berbentuk } \\
\text { persegi empat dengan bahn } \\
\text { kayu daun jendela persegi } \\
\text { panjang dengan bahan kaca } \\
\text {,dengan kuran rata-rata tinggi } \\
110 \mathrm{~cm} \text {, lebar } 80 \mathrm{~cm}\end{array}$ & \\
\hline 3 & $\begin{array}{l}\text { Gereja } \\
\text { Khatolik }\end{array}$ & $\begin{array}{l}\text { Jalan Imam Bonjol } \\
\text { Kecamatan } \\
\text { Lembah Segar } \\
\text { Kota Sawahlunto, } \\
\text { Provinsi Sumatera } \\
\text { Barat dengan arah } \\
\text { hadap utara dan } \\
\text { titik koordinat } 0^{\circ} \\
40^{\prime} 53,1^{\prime \prime} \text { LS dan } \\
100^{\circ} 46^{\prime} 40,0^{\prime \prime} \text { BT }\end{array}$ & $\begin{array}{l}\text { memiliki } 2 \text { halaman }(1 \\
\text { halaman untuk gereja, } 1 \text { untuk } \\
\text { penjaga gereja koster), } \\
\text { ruangan pada gereja terbagi } \\
\text { menjadi } 3 \text { (tempat khusus } \\
\text { pendeta, tempat para jemaat, } \\
\text { tempt penyimpanan barang } \\
\text { gereja), gereja bertingkat } 2 \\
\text { dengan jumlah anak tangga } \\
\text { 17, berbahan kayu, lantai } \\
\text { gereja berbahan keramik. } \\
\text { Sedangkan pada atap terdapat } \\
\text { motif salib dan lonceng. }\end{array}$ & $\begin{array}{l}\text { Hingga kini } \\
\text { berfungsi } \\
\text { sebagai } \\
\text { tempat } \\
\text { peribadatan. }\end{array}$ \\
\hline 4 & $\begin{array}{l}\text { Menara } \\
\text { PLTU }\end{array}$ & $\begin{array}{l}\text { Jalan Proklamasi } \\
\text { Kecamatan } \\
\text { Lembah Segar } \\
\text { Kota Sawah Lunto } \\
\text { Provinsi Sumatera } \\
\text { Barat pada titik } \\
\text { koordinat } 00^{\circ} 41^{\prime} \\
\text { 09,8' LS dan } 100^{\circ} \\
\text { 46' 40,5" BT }\end{array}$ & $\begin{array}{l}\text { Pembangkit Listrik Tenaga } \\
\text { Uap, dibangun pada tahun } \\
\text { 1894. Adapun bagian bawah } \\
\text { memiliki } 8 \text { ruas pada bagian } \\
\text { kaki yang masing-masing } \\
\text { memiliki ukuran yang sama, } \\
\text { pada menara ini juga } \\
\text { memiliki tangga sampai ke } \\
\text { atas, jumlah anak tangga } 202 \\
\text { dengan ukuran tangga lebar } \\
33 \mathrm{~cm} \text {, tebal } 10 \mathrm{~cm} \text {, menara } \\
\text { ini dulunya berwarna putih, } \\
\text { merah, sekarang berwarna } \\
\text { abu-abu, pada bagian atas } \\
\text { menara terdapat bangunan } \\
\text { kecil berbentuk segi } 8 \text {. }\end{array}$ & $\begin{array}{l}\text { Kini berubah } \\
\text { fungsi } \\
\text { menjadi } \\
\text { menara } \\
\text { Masjid } \\
\text { Nurul Huda }\end{array}$ \\
\hline 5 & $\begin{array}{l}\text { Koperasi PT } \\
\text { TBO }\end{array}$ & $\begin{array}{lr}\text { Jalan A } & \text { Yani } \\
\text { Kecamatan } \\
\text { Lembah } \\
\text { Kota Segar } \\
\text { Provinsi Sumahlunto } \\
\text { Barat pada titik } \\
\text { koordinat } 0^{\circ} 40^{\prime} \\
\text { 53,3" LS dan } 100^{\circ} \\
\text { 46' 38,2" BT. }\end{array}$ & $\begin{array}{l}\text { Bangunan ini hanya memiliki } \\
1 \text { halaman teras, bertingkat } 2 \text {, } \\
\text { memiliki pintu yang berdaun } \\
\text { ganda berbahan kayu dengan } \\
\text { motif kotak-kotak. Adapun } \\
\text { pintu tunggal berbahan kayu } \\
\text { bersengselkan besi. Ukuran } \\
\text { jendela rata-rata tinggi } 127 \\
\mathrm{~cm} \text {, lebar } 90 \mathrm{~cm} \text {, dilantai } 2 \\
\text { juga terdapat jendela yang } \\
\text { bingkai dan daunnya sama. } \\
\text { Pada bagian tingkat } 2 \text {, dinding } \\
\text { dihiasi dengan motif salib }\end{array}$ & $\begin{array}{l}\text { Kini berubah } \\
\text { menjadi } \\
\text { minang } \\
\text { mart. }\end{array}$ \\
\hline
\end{tabular}




\begin{tabular}{|c|c|c|c|c|}
\hline & & & sebanyak 11 salib. & \\
\hline 6 & Pasar Durian & $\begin{array}{lr}\text { Jalan } r & \text { Soekarno } \\
\text { Hatta Kelurahan } \\
\text { Durian } \\
\text { Kecamatan } \\
\text { Silungkang Kota } \\
\text { Sawahlunto } \\
\text { Provinsi Sumatera } \\
\text { Barat, pada titik } \\
\text { koordinat } \\
00^{\circ} 40^{\prime} 08,0^{\prime}, \text { dan } \\
100^{\circ} 45^{\prime} 44,6 \text { BT }\end{array}$ & $\begin{array}{l}\text { Bangunan berbentuk ruko } \\
\text { berlantai dua, pada salah satu } \\
\text { bangunan terdapat angka } \\
\text { tahun } 1921 \text {. Pembagian } \\
\text { ruangan rumah toko, lantai } 1 \\
\text { sebagai took, dan lantai } 2 \\
\text { sebagai tempat istirahat. Ruko } \\
2 \text { lantai ini mimiliki pintu besi } \\
\text { yang ditutup secra ditarik } \\
\text { keatas, dan memiliki jendela } \\
\text { yang masih berbahan kayu } \\
\text { berbentuk segi empat. }\end{array}$ & $\begin{array}{l}\text { Beralih } \\
\text { fungsi } \\
\text { menjadi } \\
\text { tempat } \\
\text { tinggal } \\
\text { warga di } \\
\text { Sawahlunto }\end{array}$ \\
\hline 7 & $\begin{array}{l}\text { Perpustakaan } \\
\text { Adinegoro }\end{array}$ & $\begin{array}{l}\text { Jalan A Yani } \\
\text { Kecamatan } \\
\text { Lembah Segar } \\
\text { Kota Sawahlunto, } \\
\text { Provinsi Sumatera } \\
\text { Barat dengan titik } \\
\text { koordinat } 0^{\circ} 41^{\prime} \\
\text { 01,0" LS dan } 100^{\circ} \\
\text { 46' 40,7” BT. }\end{array}$ & $\begin{array}{l}\text { Bangunan ini bertingkat } 2 \text {, } \\
\text { memiliki } 1 \text { halaman teras, } \\
\text { memiliki pintu yang berdaun } \\
\text { ganda dengan bentuk persegi } \\
\text { panjang dan memiliki jendela } \\
\text { berdaun tunggal dengan } \\
\text { bahan bingkai kayu dan bahan } \\
\text { daun kaca. Adapun lantai } \\
\text { perpustakaan keramik, pada } \\
\text { bagian atas beratapkan seng. }\end{array}$ & $\begin{array}{l}\text { Dahulu } \\
\text { perpustakaan } \\
\text { ini dijadikan } \\
\text { sebgaai eks } \\
\text { bioskop } \\
\text { kolonial. }\end{array}$ \\
\hline 8 & $\begin{array}{l}\text { Mesjid } \\
\text { Nurul Huda }\end{array}$ & $\begin{array}{l}\text { Kelurahan Durian } \\
\text { 1, Kecamatan } \\
\text { Baringin Kota } \\
\text { Sawahlunto, } \\
\text { Provinsi Sumatera } \\
\text { Barat, dengan letak } \\
\text { astronomis } 0^{\circ} 40^{\prime} \\
\text { 07,0" LS dan } 100^{\circ} \\
\text { 45'45,0"BT. }\end{array}$ & 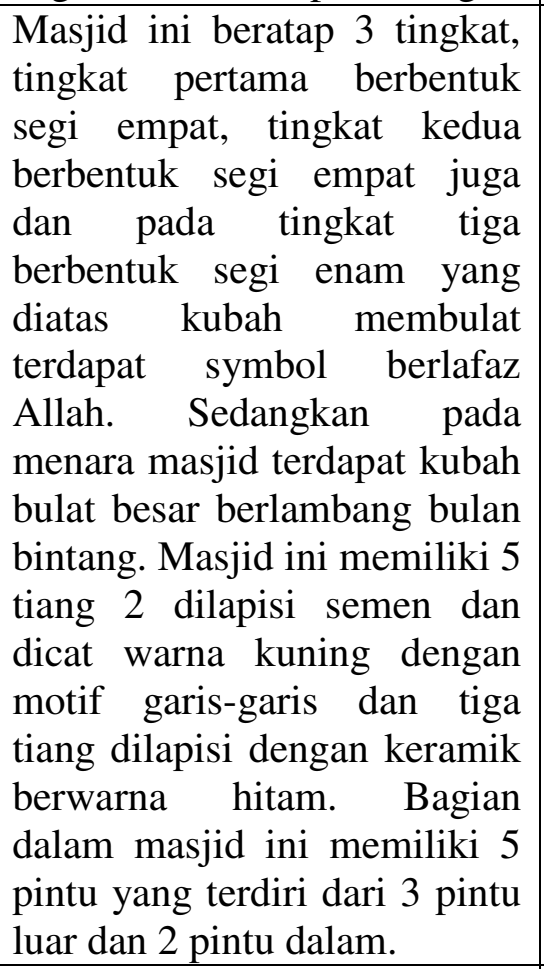 & $\begin{array}{l}\text { Berfungsi } \\
\text { sebagai } \\
\text { tempat } \\
\text { peribadatan. }\end{array}$ \\
\hline 9 & Dinas UPO & $\begin{array}{l}\text { kelurahan Saringan } \\
\text { kecamatan } \\
\text { Baringin Kota } \\
\text { Sawahlunto } \\
\text { provinsi Sumatera } \\
\end{array}$ & $\begin{array}{l}\text { Bangunan kantor UPO ini } \\
\text { memiliki bentuk yang unik } \\
\text { karena bentuk bangunan akan } \\
\text { semakin megecil bagian atas. } \\
\text { Bentuk atap bangunan ini }\end{array}$ & $\begin{array}{l}\text { Tetap } \\
\text { memiliki } \\
\text { fungsi yang } \\
\text { sama yakni } \\
\text { sebagai }\end{array}$ \\
\hline
\end{tabular}




\begin{tabular}{|c|c|c|c|c|}
\hline & & $\begin{array}{l}\text { Barat } r \text { letak } \\
\text { astronomisnya } 0^{\circ} \\
40^{\prime} 25,5^{\prime} \text { LS dan } \\
100^{\circ} 46^{\prime} 03,9^{\prime \prime} \mathrm{BT} \text {. }\end{array}$ & $\begin{array}{l}\text { adalah limas di atap lantai } 1 \\
\text { dan } 2 \text { namun berbentuk } \\
\text { segiempat kerucut di lantai } 3 \text {. } \\
\text { Adapun jumlah jendela pada } \\
\text { bangunan ini, di lantai } 1 \\
\text { jumlah jendela adalah } 30 \text {, } \\
\text { lantai } 2 \text { ada } 5 \text { jendela dan } \\
\text { lantai } 3 \text { juga memiliki } 5 \\
\text { jendela, dengan ukuran rata- } \\
\text { rata tinggi } 246 \mathrm{~cm} \text { dengan } \\
\text { lebar } 120 \mathrm{~cm} \text {. }\end{array}$ & $\begin{array}{l}\text { Kantor } \quad \text { PT } \\
\text { TBO. }\end{array}$ \\
\hline 10 & $\begin{array}{l}\text { Rumah } \\
\text { Dokter } \\
\text { Ikhsan }\end{array}$ & $\begin{array}{l}\text { Kelurahan Pasar, } \\
\text { Kecamatan } \\
\text { Lembah Segar, } \\
\text { Kota Sawahlunto, } \\
\text { Provinsi Sumatera } \\
\text { Barat, dengan letak } \\
\text { astronomisnya } 0^{\circ} \\
40^{\prime} 51,7^{\prime} \text { LS dan } \\
100^{\circ} 46^{\prime} 40,1^{\prime \prime} \text { BT. }\end{array}$ & $\begin{array}{l}\text { Bagian atap rumah berbentuk } \\
\text { limas dengan bahan genteng. } \\
\text { Tiang pada bagian teras depan } \\
\text { berjumlah } 4 \text { dengan bentuk } \\
\text { bulat dan bahan coran semen } \\
\text { sedangkan tiang teras } \\
\text { belakang berbentuk persegi } \\
\text { dengan bahan kayu. Jendela } \\
\text { rumah ini berjmlah } 11 \text { yaitu } 1 \\
\text { bagian barat } 6 \text { bagian utara } \\
\text { dan } 4 \text { bagian selatan. }\end{array}$ & $\begin{array}{l}\text { Kini } \\
\text { bangunan ini } \\
\text { beralih } \\
\text { fungsi } \\
\text { menjadi } \\
\text { homestay } \\
\text { untuk } \\
\text { wisatawan. }\end{array}$ \\
\hline 11 & $\begin{array}{l}\text { Sekolah } \\
\text { Santa Lucia }\end{array}$ & 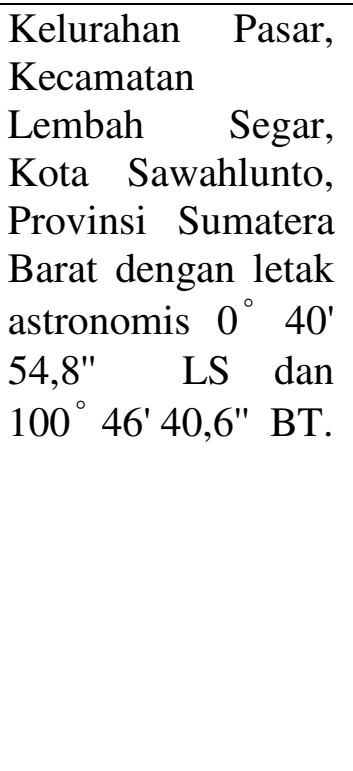 & $\begin{array}{l}\text { Bangunan yang } \begin{array}{r}\text { didirikan } \\
\text { tahun } 1920,\end{array} \text { dahulu } \\
\text { merupakan sekolah orang } \\
\text { Eropa yang ada di } \\
\text { Sawahlunto. Bangunan ini } \\
\text { berlantai 2, dimana terdapat } 3 \\
\text { pintu di lantai 1, dan } 2 \text { pintu } \\
\text { dan lantai 2. Sedangkan } \\
\text { jumlah jendela bangunan ini } \\
\text { sebanyak } 17 \text { jendela, } 8 \text { pada } \\
\text { lantai } 1 \text { dan } 9 \text { jendela di lantai } \\
2 \text {, yang secara keseluruhan } \\
\text { berbentuk sama dengan motif } \\
\text { garis-garis. Adapun Atap } \\
\text { bangunan ini berbentuk limas } \\
\text { berbahan dari seng. }\end{array}$ & $\begin{array}{l}\text { Tetap } \\
\text { difungsikan } \\
\text { sebagai } \\
\text { sekolah } \\
\text { dasar. }\end{array}$ \\
\hline 12 & $\begin{array}{l}\text { Museum } \\
\text { Gudang } \\
\text { Ransoem }\end{array}$ & $\begin{array}{l}\text { Kelurahan Pasar, } \\
\text { Kecamatan } \\
\text { Lembah Segar, } \\
\text { Kota Sawahlunto, } \\
\text { Provinsi Sumatera } \\
\text { Barat, dengan letak } \\
\text { astronomis } 0^{\circ} 40^{\prime} \\
\text { 44,0" LS dan } 100^{\circ} \\
46^{\prime} 51,4^{\prime} \text { BT. }\end{array}$ & $\begin{array}{l}\text { Bangunan berbentuk persegi } \\
\text { panjang ini berlantai dua, } \\
\text { dengan bagian basement } \\
\text { dibawahnya. Diatas basement } \\
\text { terdapat ruang dengen } \\
\text { tungku-tungku } \\
\text { berjumlah } 2 \text { tungku yang } \\
\text { besar dan yang kecil disini } \\
\text { juga terdapat } 2 \text { kuali dan } \\
\text { sendok pengaduk yang sangat }\end{array}$ & $\begin{array}{l}\text { Dahulu } \\
\text { difungsikan } \\
\text { sebagai } \\
\text { dapur } \\
\text { umum, amun } \\
\text { kini beralih } \\
\text { fungsi } \\
\text { sebagai } \\
\text { museum. }\end{array}$ \\
\hline
\end{tabular}




\begin{tabular}{|l|l|l|}
\hline & $\begin{array}{l}\text { besar. Terdapat } 3 \text { pintu bagian } \\
\text { depan, dan 5 jendela bagian } \\
\text { depan serta } 2 \text { bagian } \\
\text { belakang. Adapun bagian atap } \\
\text { terdiri dari 3 tingkatan } \\
\text { berbentuk limas. }\end{array}$ \\
\hline
\end{tabular}

Wajah Arsitektur Bangunan Kolonial

\section{Kota Tambang Sawahlunto.}

Berdasarkan data identifikasi pada sub-bab sebelumnya, maka dapat dikatakan ragam bangunan di Sawahlunto cukup beragam, baik secara bentuk, fungsi, maupun tahap pembangunan. Sebelum sampai pada titik akhir pertanyaan penelitian yakni mempertayakan gaya arsitektur yang dihadirkan di Kota Tambang Sawahlunto, maka terlebih dahulu dilakukan analisis morfologi/bentuk, fungsi, dan taapan pembangunan yang pernah berlangsung di Kota Tambang Sawahlunto. Secara terperinci, analisis morfologi, fungsi dan tahapan pembangunan bangunan kolonial Sawahlunto diurakan terperinci pada tabel 2 sebagai berikut.

Tabel 2.

Bangunan Rumah Tinggal

\begin{tabular}{|c|l|l|}
\hline No & \multicolumn{1}{|c|}{$\begin{array}{c}\text { Analisis } \\
\text { Morfologi-Fungsi }\end{array}$} & \multicolumn{1}{c|}{ Uraian Analaisis } \\
\hline 1 & $\begin{array}{l}\text { Bangunan Rumah } \\
\text { Tinggal }\end{array}$ & $\begin{array}{l}\text { Kategori bangunan rumah tinggal dilihat dari fungsi } \\
\text { masa lalu bangunan kolonial yang terdapat di Kota } \\
\text { Lama Tambang Batubara Sawahlunto yaitu Rumah dr } \\
\text { Ichsan, Pasar Durian. }\end{array}$ \\
\hline
\end{tabular}
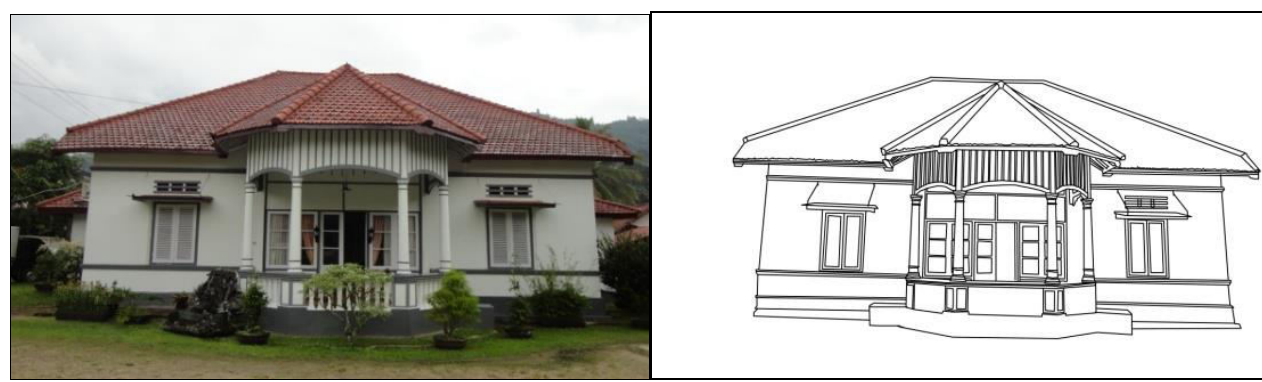

Gambar tampak depan Rumah dr.Ichsan

(Dok; Foto dan digitasi oleh Hanif, 2018)

Dari hasil tabel 2, dan data yang telah dikalasifikasikan, bahwa terdapat ciri khas yang menunjukkan kecendrungan kolonial terhadap bangunan rumah yang terdapat di Kota Lama Tambang Batubara Sawahlunto. 


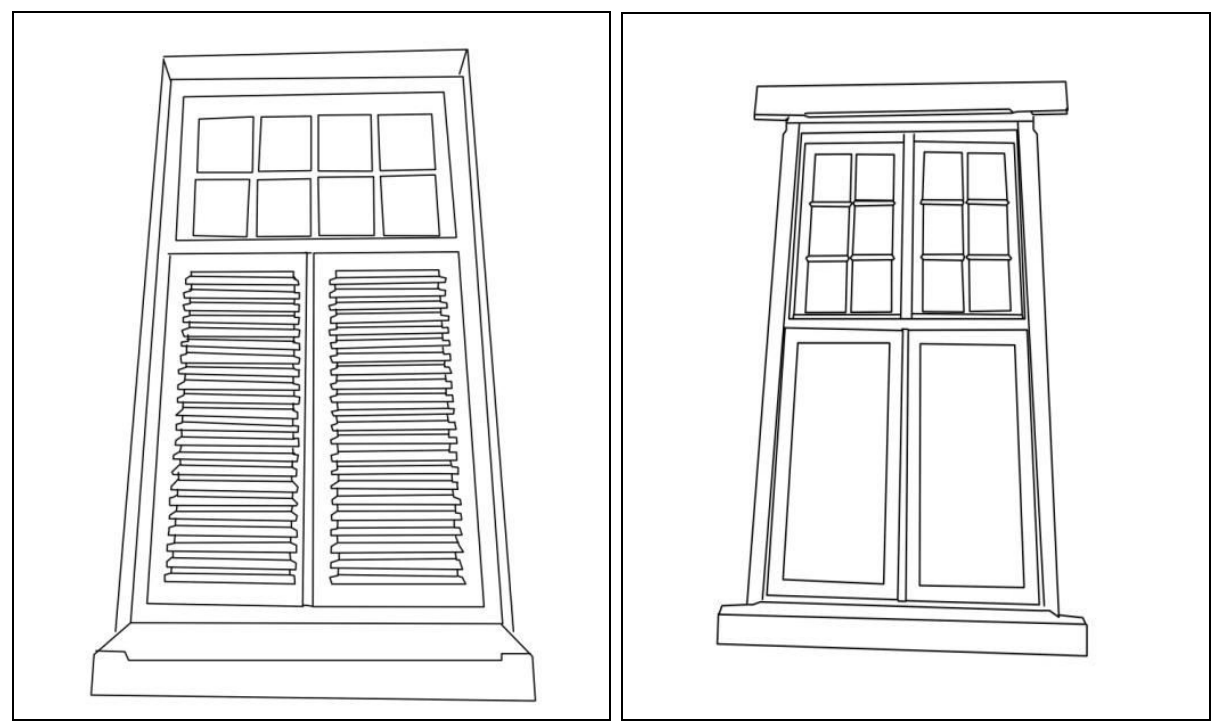

Jendela Sekolah Santa Lucia dan Kantor Dinas UPO (Digitasi Oleh Hanif, 2018)

Ciri lain terletak pada jendela rumah yang sebagian besar berbentuk persegi panjang bermotif garis-garis dengan rongga-rongga disetiap garisnya, daun jendela kebanyakan berdaun ganda dan memiliki dormer disetiap jendelanya. Demikian juga pada pintu yang rata-rata bermotif kotak-kotak dengan bahan kayu, sedangkan pada pintu utama juga menggunakan daun pintu ganda dan kaca di motif kotak bagian atas. Ciri-ciri ini juga dapat dilihat pada rumah Dokter. Ichsan dan rumah kejaksaan yang memiliki teras dibagian belakangnnya.

Selain bangunan rumah tinggal, bentuk dan fungsi lain yang berdaarkan data identifikasi serta klasifikasi yakni dikategorikan bangunan pelayanan umum/bangunan publik, sebagaimana dipaparkan dalam tebel 3 berikut.

Tabel 3.

Analisis Bangunan Pelayanan Umum

\begin{tabular}{|l|l|l|}
\hline No & \multicolumn{1}{|c|}{$\begin{array}{c}\text { Analisis } \\
\text { Morfologi-Fungsi }\end{array}$} & \multicolumn{1}{c|}{ Uraian Analisis } \\
\hline 2 & $\begin{array}{l}\text { Bangunan } \\
\text { Pelayanan Umum }\end{array}$ & $\begin{array}{l}\text { Kategori bangunan pelayanan umum dilihat dari fungsi } \\
\text { masa lalu, yaitu Kantor Koperasi PT TBO, Perpustakaan } \\
\text { Adinegoro, Museum Gudang Ransoem, Sekolah Santa } \\
\text { Lucia, Dinas UPO. }\end{array}$ \\
\hline
\end{tabular}




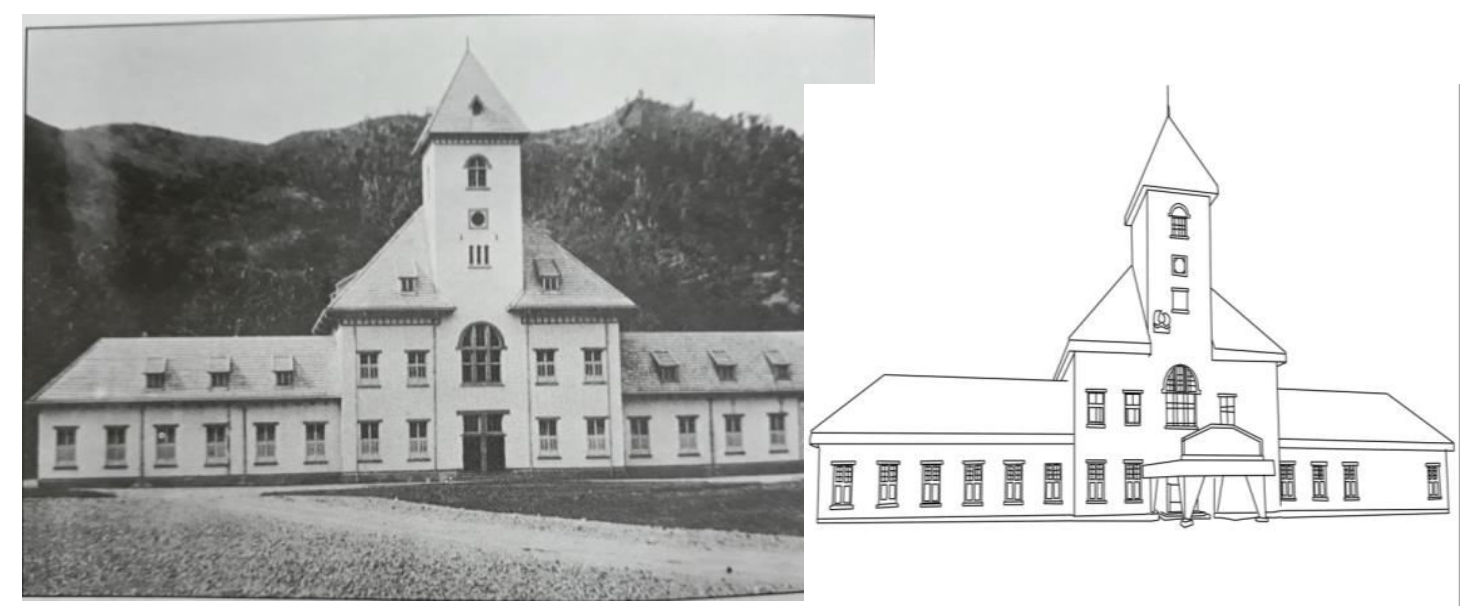

Kantor Dinas UPO tampak depan (Digitasi Oleh Hanif, 2018)

Dilihat dari bentuk atap bangunan tersebut, terdapat cirikhas hiasan puncak atap dengan arsitektur bergaya Belanda yang kental pyramid yang mengerucut. Bentuk ini dapat ditemukan juga semisal pada atap bangunan pasar durian, dan koperasi PT TBO. Selain itu, perpustakaan Adinegoro yang merupakan Ex-bioskop

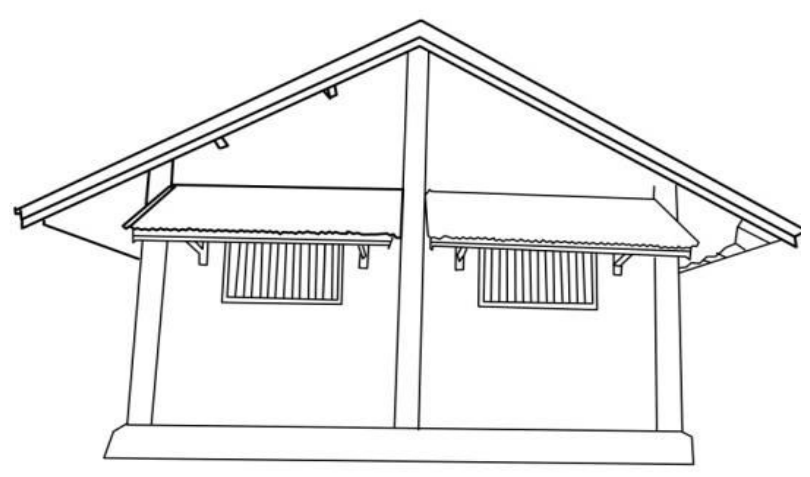

memiliki ciri ciri jendela dengan bentuk persegi empat berdaun jendela 2, pada bagian tingkat 2 juga memiliki jendela yang menyatu dengan ventilasi, jendela masih berbentuk sama, bentuk ini juga dapat kita jumpai pada juga gereja katholik, serta bangunan stasiun Muara Kalaban dan Silungkang.

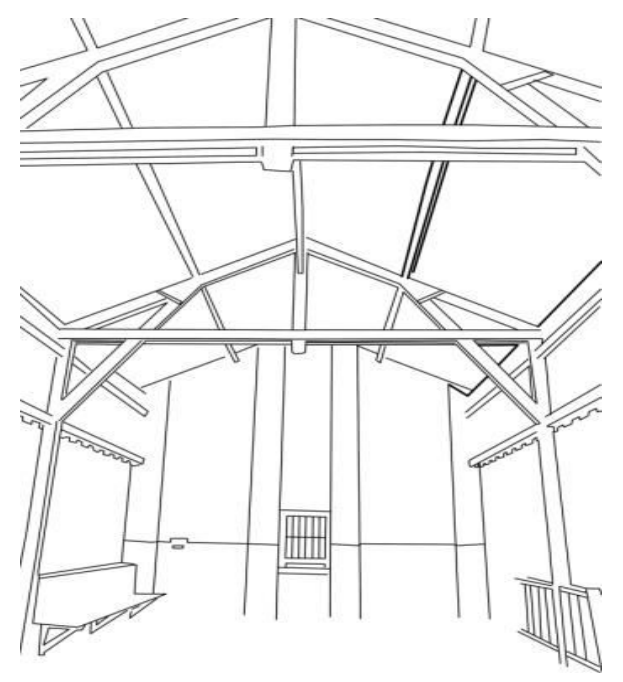

Gudang Ransoem dan Stasiun Muara Kalaban

(Digitasi Oleh Hanif dan Nurul, 2018) 
Kategori ketiga dari klasifikasi bangunan kolonial yang terdapat di Kota Sawahlunto, adalah kategori bangunan Ibadah. Klaisfikasi banguann ini ditandai dari beberapa ciri morfologi, serta dilandasi atas dasar analisis fungsi bangunan, yang secara terperinci dipaparkan dalam tabel 4 berikut.

Tabel 4.

Analisis Bangunan Ibadah

\begin{tabular}{|l|l|l|}
\hline No & $\begin{array}{c}\text { Analisis Morfologi- } \\
\text { Fungsi }\end{array}$ & \multicolumn{1}{c|}{ Uraian Analisis } \\
\hline 3 & Bangunan Ibadah & $\begin{array}{l}\text { Kategori bangunan ibadah dilihat dari Bentuk dan } \\
\text { fungsi masa lalunya, yaitu Gereja Katholik, dan Masjid } \\
\text { Nurul Huda. Gereja katholik yang terletak ini memiliki } \\
\text { arsitektur eropa, yang terlihat dari bentuk kemuncak } \\
\text { pada atap serta hiasan lengkung pada bagian atasnya. } \\
\text { Ciri ini lain seperti simbol salib di bagian dinding dan } \\
\text { bagian atap. Pada masjid Nurul Huda, ciri serupa juga } \\
\text { terdapat, yakni dilhat dari bentuk atap berkemuncak } \\
\text { dan terdapat symbol Allah diatas kubah bangunan } \\
\text { masjid. Secara fungsi, keduanya digunakan untuk } \\
\text { tempat ibadah. }\end{array}$ \\
\hline
\end{tabular}

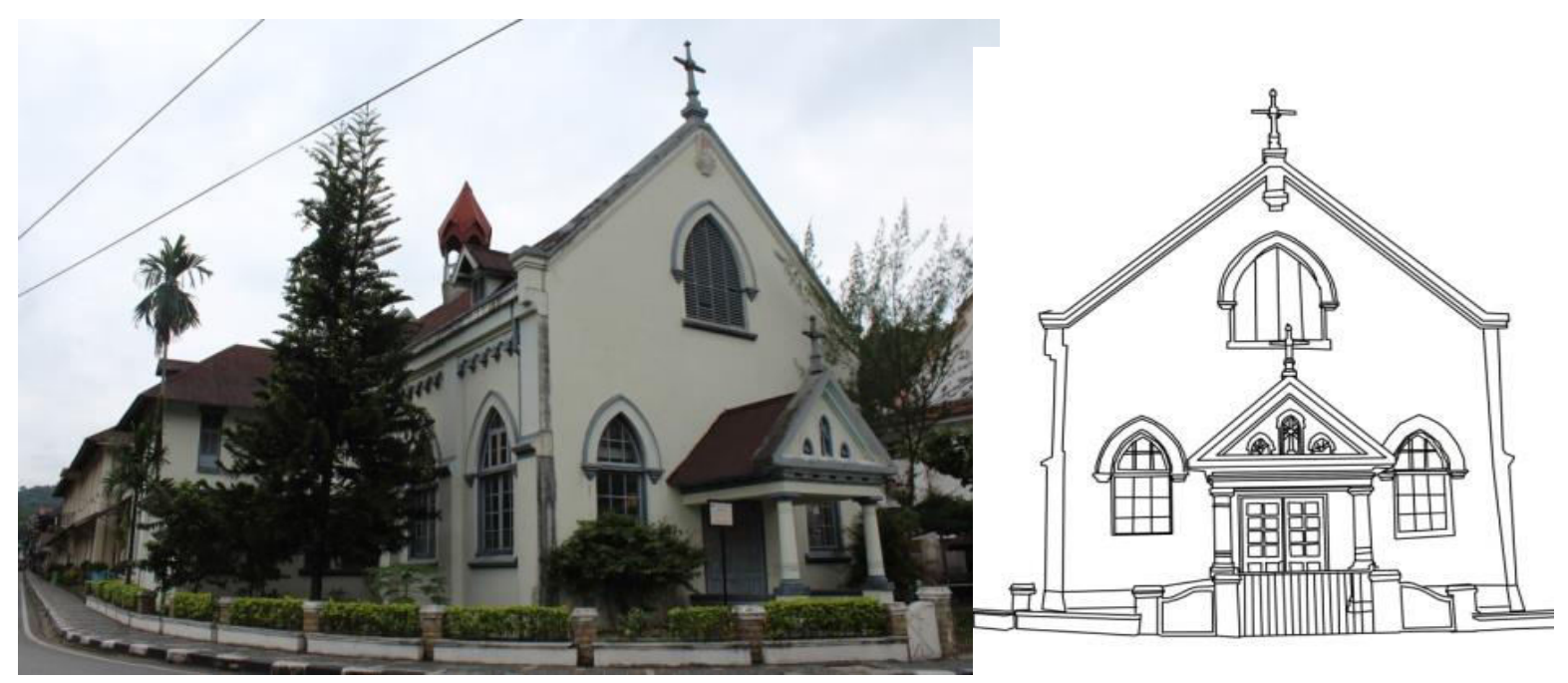

Gereja Santa Lucia dan Koperasi PT TBO

(Dok; Nurul, 2018)

Bangunan kolonial yang fungsi ini disesuaikan dengan terdapat di Kota Lama Tambang Batubara Sawahlunto memiliki fungsi yang berbeda-beda setiap bangunannya, kebutuhan pada saat itu. Adanya perbedaan tersebut, sebab keberadaan bangunan-bangunan yang ada 
merupakan bangunan pendukung demi berjalannya kegiatan pertambangan batubara yang terdapat di kota Sawahlunto. Menariknya, sebagian besar bangunan masih digunakan sebagai sarana prasarana yang terdapat di Sawahlunto, semisal rumah dinas, bank, koperasi, hotel dan lain-lain.

Kemudian dapat ditarik suatu kesimpulan bahwa secara bentuk dan fungsi, ada 3 bentuk dan fungsi bangunan koloial yang terdapat di Sawahlunto, yakni 1) bangunan rumah tinggal, 2) bangunan ibadah, 3) bangunan layanan umum.

Pembangunan Kota Sawahlunto tidak terlepas dari kondisi politik di Eropa aabad 19, yang kemudian dikenal politik etis. Hal ini kemduian membawa gagasan besar, yang dikenal dengan sebutan pembangunan proyek tiga serangkai yaitu pembangunan Emma Haven (Teluk Bayur), Rel Kereta Api, dan Tambang Batubara Ombilin (Lindayanti. 2016). Secara bertahap, Kota Tambang Sawahlunto berkembang mengisi ruang wilayah yang ada. Semisal pembangunan rel kereta api yang dibangun dalam 3 tahap, yaitu tahap pertama dari Teluk BayurPadangpanjang. Tahap kedua Padangpanjang-Solok-Muara Kalaban.
Tahap ketiga Muara KalabanSawahlunto yang diresmikan pada 01 Oktober 1892.

Semenjak pembangunan proyek tiga serangkai mulai dilakukan pembangunan sarana-sarana penunjang lainnya mulai banyak dibangun untuk kelancaran aktivitas perekonomian ataupun lainnya. Pembangunan dalam bidang ekonomi meliputi koperasi yang digunakan sebagai tempat peminjaman dan menyimpan uang. Kemudian pembangunan di lanjutkan dengan di bangunnya gedung atau pusat hiburan untuk bangsawan dari PT TBO yang di bangun tepat di tengah-tengah kota Sawahlunto, seperti halnya bangunan bioskop sebagai tempat hiburan para karyawan PT TBO yang sekarang beralih fungsi menjadi tempat perpustakaan Adinegoro.

Pembangunan sarana ini juga dilakukan dalam beberapa tahap yang telah diklasifikasikan oleh peneliti dalam 3 tahap. Tahap awal yaitu tahun 1882-1900 yang berfungsi sebagai sarana umum yaitu sekolah Santa Lucia. Tahap tengah yaitu tahun 1900-1920 yang berfungsi sebagai rumah tinggal dan pelayanan umum. Tahap akhir yaitu tahun 1920-1959 yang berfungsi sebagai kantor layanan umum. 
Pembagian tahap pembangunan bangunan kota Sawahlunto dilihat dari cirikhas setiap bangunan yang berbedabeda pada setiap bangunannya.

Tahun 1868 penemuan tambang batubara di kota sawahlunto oleh de Grave membawa perkembangan yang signifikan terhadap pertumbuhan di kota Sawahlunto. Berdasarkan temuan bantalan rel kereta api tercatat yang paling tua adalah tahun 1888. Berdasarkan database yang didapat pembangunan sarana prasarana adalah pembangunan gedung sekolah Santa Lucia pada tahun 1882. Penentuan tahapan pembangunan dalam penelitian ini dilakukan dengan komparasi terhadap bangunan yang memiliki tahun pembuatan sehingga dapat dilakukan penentuan tahapan pembangunan bangunan.

\section{Gaya Arsitektur Kota Sawahlunto}

Bangunan kolonial yang terdapat di Sawahlunto memiliki ciri khas tersendiri yang berpatokan sesuai dengan fungsinya, seperti beberapa bangunan rumah tinggal yang ciricirinya berupa banyak bagian-bagian ruangan didalam rumah, memiliki teras dipintu depan/pintu utama, dan memiliki dormer ditiap jendelanya. Fungsi lahan Sawahlunto sebagai sebuah kota tambang mengakibatkan fokus perkembangannya pada infrastruktur tambangnya. Setiap bangunan yang ada di sawahlunto tidak banyak gaya estsitis/seni yang menonjol dan berlebihan, seperti bangunanbangunan kolonial umumnya di wilayah lain yang mengutamakan keindahan dan kemegahan, semisal Lawang Sewu di Semarang. Hanya dua bangunan yang terlihat sedikit lebih megah, hal ini juga dikarenakan fungsi khususnya. Seperti rumah dokter.Ichsan yang arsitektur bangunannya terlihat apik, rapi, tertata, lebih besar dari pada rumah tinggal lainnya. Berdasarkan letak, menjadi ciri kantor pelayanan umum yang ada di Sawahlunto yang ditempatkan di persimpangan sehingga memudahkan publik mendatangi bangunan pelayanan umum. Dapat dikatakan, bahwa gaya seni arsitektur kolonial di Sawahlunto lebih mementingkan fungsi dari pada seni estetik/keindahan, sehingga gaya seni arsitektur Eropa tidak begitu ditonjolkan seperti bangunan kolonial lainnya yang megah dan kaya akan seni arsitektur.

\section{KESIMPULAN}

Kota Lama Tambang Batubara Sawahlunto berkembang pesat setelah ditemukannya bongkahan-bongkahan 
emas hitam atau batubara oleh de Grave pada tahun 1868. Perkembangan pembangunan yang terjadi karena penemuan de Grave terhadap sumber daya alam yang berupa batubara yang akan di ekspor keberbagai negara diluar nusantara. Perkembangan ini didahului dengan proyek tiga serangkai yaitu Emma Haven (Teluk Bayur), Rel Kereta Api, Lubang Tambang Ombilin. Sebelum pembangunan proyek tiga serangkai terlebih dahulu salah satu sarana telah dibangun yaitu sekolah Santa Lucia pada tahun 1882. Bangunan pendukung di Sawahlunto dibagi menjadi bangunan rumah tinggal, bangunan layanan umum/publik, bangunan ibadah. Secara kronologi waktu, bangunan kolonial yang terdapat di Sawahlunto dibangun dalam beberapa tahapan, seperti pembangunan pada rel kereta api yang juga dibangun dalam beberapa tahap yaitu 3 tahap. Dikarenakan guna lahan kawasan Sawahlunto yang difokuskan kepada kegiatan penambangan Batubara, maka wajah bangunan yang diciptakan juga terlihat kaku, simetris yang presisi, atau dengan kata lain tidak banyak mendapat sentuhan seni estetis dan kemegahan yang mencolok, sebagaimana banguanan kolonial pada umumnya.
Dari segi pengaruh seni estetis lokal/Minagkabau, atau etnis lain, juga minim ditemukan. Mungkin ada benarnya pameo yang mengatakan bahwa orang-orang teknik cenderung terlalu serius, dan memandang segala sesutau hanya pada guna dan fungsi saja.

\section{DAFTAR PUSTAKA}

Asoka, Andi. Sawahlunto Dulu, Kini dan Esok: Menjadi Kota Wisata Tambang yang Berbudaya. Minangkabau Press. Sumatera Barat.

Cherish, Rika. The Picture op Mining Town of Sawahlunto in The Past.Kota Sawahlunto.

Laporan Penelitian Metode Arkeologi II. 2018. Penelitian Arkeologi Kolonial Di Kota Tambang Kolonial Sawahlunto. Program Studi Arkeologi Universitas Jambi: Jambi.

Lindayanti, dkk. 2017. Kota Sawahlunto, Jalur Kereta Api dan Pelabuhan Teluk Bayur: Tiga Serangkai dalam Sejarah Pertambangan Batubara Ombilin di Sumatera Barat. Minangkabau Press. Sumatera Barat.

Pertambangan dan Pengangkutan Batubara Ombilin Sawhlunto pada Masa Kolonial. Minangkabau Press. Sumatera Barat.

Sadzali, A., \& Anra, Y. (2018). RAGAM ARSITEKTUR RUMAH TRADISIONAL MELAYU JAMBI: SUATU KAJIAN ARKEOLOGI ARSITEKTUR DALAM UPAYA PELESTARIAN WARISAN BUDAYA DAN PEMAJUAN KEBUDAYAAN 
MELAYU JAMBI. Titian: Jurnal Ilmu Humaniora, 2(02), $300 \quad$-. Retrieved from https://online-

journal.unja.ac.id/titian/article/vi ew/5812

Sadzali, A., \& Fitrah, Y. (2018). KAJIAN SENI ISLAM ARSITEKTUR DAN RAGAM HIAS MESJID KUNO DI DATARAN TINGGI JAMBI: SUATU KAJIAN ARKEOLOGI ISLAM DALAM UPAYA MELESTARIKAN DAN MENGEMBANGKAN ISLAM MELAYU JAMBI. Titian: Jurnal Ilmu Humaniora, 2(02), 323 -. Retrieved from https://online-

journal.unja.ac.id/titian/article/vi ew/5813

Soekiman, Djoko. 2011. Kebudayaan Indis: Dari Zaman Kompeni Sampai Revolusi. Komunitas Bambu. Jakarta.

Sukendar, Haris. 1999. Metode Penelitian Arkelogi. Pusat Penelitian Arkeologi Nasional: Jakarta.

Sumalyo, Yulianto. 1993. Arsitektur Kolonial Belanda di Indonesia. Gadjah Mada University Press. Yogyakarta.

Suprayoga, Gede Budi. 2008. Identitas Kota Sawahlunto Paska Kejayaan Pertambangan Batubara. Dalam Jurnal Perencanaan Wilayah dan Kota, Vol.19/No.2 Agustus, 2008.

Tim. 1999. Metode Penelitian Arkeologi. Jakarta. Departemen Pendidikan Nasional Pusat Penelitian Arkeologi Nasional. 